\title{
Function Indicator Device
}

National Cancer Institute

\section{Source}

National Cancer Institute. Function Indicator Device. NCI Thesaurus. Code C50002.

A device designed to monitor a specific function of a system. 